\title{
Bacillus macauensis sp. nov., a long-chain bacterium isolated from a drinking water supply
}

Correspondence

Herbert H. P. Fang

hrechef@hkucc.hku.hk

\author{
Tong Zhang, ${ }_{1}^{1}$ Xiaojun Fan, ${ }^{2}$ Satoshi Hanada, ${ }^{3}$ Yoichi Kamagata ${ }^{3}$ \\ and Herbert H. P. Fang ${ }^{1}$ \\ ${ }^{1}$ Centre for Environmental Engineering Research, Department of Civil Engineering, \\ The University of Hong Kong, Pokfulam Road, Hong Kong, China \\ ${ }^{2}$ The Macao Water Supply Company Ltd, Macau, China \\ ${ }^{3}$ Institute for Biological Resources and Functions, National Institute of Advanced Industrial \\ Science and Technology (AIST), Tsukuba, Japan
}

At the time of writing, the genus Bacillus consists of 226 aerobic or facultatively anaerobic spore-forming species that are ubiquitous in nature. Their presence has been found in soil, water and even airborne dust (Berkeley et al., 2002). Cells of Bacillus species are straight-sided with rounded or square ends. Most of them grow as single cells, but a few may form chains and filaments. The filamentous Bacillus species may be either pathogenic, such as Bacillus anthracis (Berkeley et al., 2002), or non-pathogenic, such as Bacillus funiculus (Ajithkumar et al., 2002) and Bacillus mycoides (von Klopotek, 1969). Long-chain Bacillus species have been isolated from wastewater-treatment systems (Ajithkumar et al., 2002) and soil (von Klopotek, 1969), but (so far) not from drinking water supplies. In this study, we report on the taxonomic characterization of a novel long-chain Bacillus bacterium, strain ZFHKF-1 ${ }^{\mathrm{T}}$, which was isolated from the drinking water supply of Macau, a city of subtropical climate located at the mouth of the Pearl River in China.

Strain ZFHKF-1 ${ }^{\mathrm{T}}$ was isolated, using Luria-Bertani agar medium, from water conveyed to the Macao Water Supply Company from the West River, upstream of Pearl River. The

Published online ahead of print on 2 December 2005 as DOI 10.1099/ ijs.0.63868-0.

The GenBank/EMBL/DDBJ accession number for the 16S rRNA gene sequence of strain $\mathrm{ZFHKF-1}{ }^{\top}$ is $\mathrm{AY} 373018$.
Gram-staining and endospore-forming features of this isolate were examined using a light microscope (E600; Nikon). The morphology was investigated using a confocal laser scanning microscope (PASCAL 5; Zeiss) after staining of the cells using SYTO9 (Molecular Probe). The ultrastructure was examined using a transmission electron microscope (100SX; JEOL) and a scanning electron microscope (Cambridge-360; Leica Cambridge). The cells of ZFHKF-1 ${ }^{\mathrm{T}}$ were rod-shaped, $0 \cdot 8-1 \cdot 2 \mu \mathrm{m}$ in diameter and $2 \cdot 0-5 \cdot 0 \mu \mathrm{m}$ in length (Fig. 1a, b) and formed long chains in both liquid and solid media. In solid medium, the cells formed large, white, opaque, irregularly shaped, flatly spread colonies with fuzzy boundaries. The long chains were intertwined within the colony-forming clusters (Fig. 1c), which did not appear to have any regular pattern. The ZFHKF- $1^{\mathrm{T}}$ cells in the colony grew into long unbranched chains over $100 \mu \mathrm{m}$ in length (Fig. 1d). In liquid medium, the cells formed flocs with a net-like structure.

Strain ZFHKF- $1^{\mathrm{T}}$ was facultatively anaerobic and mostly Gram-positive. It degraded glucose under anaerobic conditions without producing gas. It was catalase-positive and capable of hydrolysing gelatin and forming swollen endospores. Tests to determine the optimum temperature and $\mathrm{pH}$ for cell growth were conducted in $150 \mathrm{ml}$ flasks containing Luria-Bertani medium and with shaking at 60 r.p.m. Cell concentrations were based on $\mathrm{OD}_{660}$ measurements. Glass 

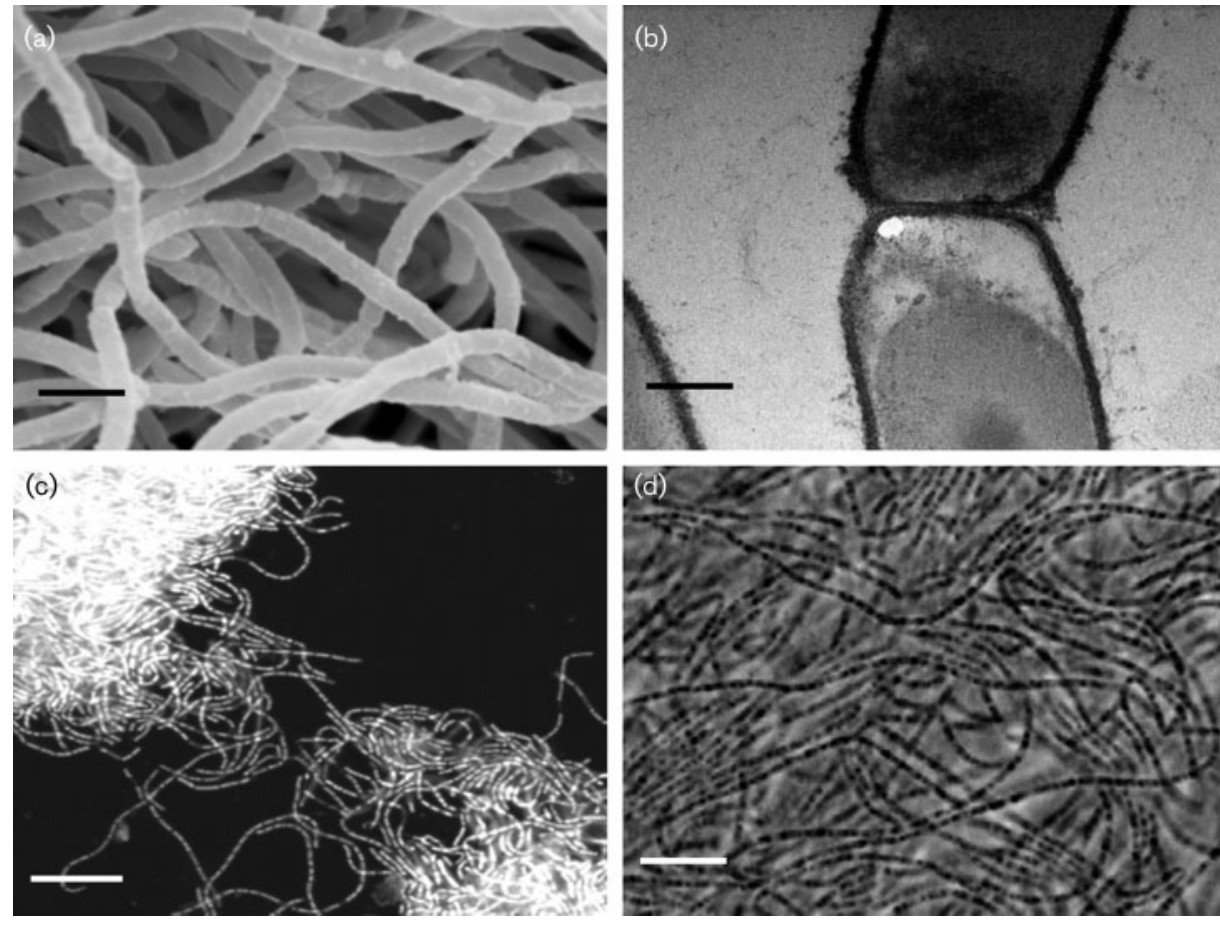

Fig. 1. Images of ZFHKF-1 $1^{\top}$. (a) Scanning electron microscope image showing the long chains. (b) Transmission electron microscope image showing the connection between two adjacent cells. (c) Confocal laser scanning microscope image of cell clusters in the solid Luria-Bertani medium. (d) Phase-contrast microscope image of a cell cluster in Luria-Bertani medium.

Bars: (a) $2 \mu \mathrm{m}$; (b) $0.5 \mu \mathrm{m}$; (c) $10 \mu \mathrm{m}$; (d) $8 \mu \mathrm{m}$.

beads were added to the incubation flasks for the dispersal of cells. Strain ZFHKF- $1^{\mathrm{T}}$ grew at $\mathrm{pH} 6 \cdot 0-10 \cdot 0$ at $25^{\circ} \mathrm{C}$, with an optimum at $\mathrm{pH} 8 \cdot 5$, indicating its tolerance of slightly alkaline conditions. It grew at $20-40{ }^{\circ} \mathrm{C}$ at $\mathrm{pH} 8 \cdot 5$, with an optimum growth temperature of $30^{\circ} \mathrm{C}$. No growth was observed above $45^{\circ} \mathrm{C}$ after 40 days incubation. The cells survived heat treatment at $80^{\circ} \mathrm{C}$ for $10 \mathrm{~min}$. Growth was slightly inhibited by $\mathrm{NaCl}$ at $20 \mathrm{~g} \mathrm{l}^{-1}$, and was completely inhibited by $\mathrm{NaCl}$ at $50-100 \mathrm{~g} \mathrm{l}^{-1}$.

The metabolic profile of strain ZFHKF- $1^{\mathrm{T}}$ was examined using the Biolog system, which included an array of 96 wells for the oxidation of 95 carbon sources. Sample preparation and analysis was performed according to the directions of the manufacturer (Biolog). The triplicate microplates were read, after 4 and $24 \mathrm{~h}$ incubation, using the Microstation hardware (Biolog), and the data were analysed using MICROLOG 3 software (Biolog). Of the 95 carbon sources tested, 22 could be oxidized by the isolate: $\beta$-cyclodextrin, cellobiose, D-galactose, gentiobiose, $\alpha$-D-glucose, lactulose, maltose, maltotriose, D-mannitol, D-mannose, 3-methyl glucose, L-rhamnose, D-ribose, sedoheptulosan, $\alpha$-ketoglutaric acid, L-malic acid, monomethyl succinic acid, L-glutamic acid, glycyl L-glutamic acid, uridine, uridine $5^{\prime}$-monophosphate and glucose 1-phosphate. Oxidation of 55 of the remaining carbon sources varied among the three replicate microplates: inulin, mannan, $N$-acetyl-D-glucosamine, $\mathrm{N}$-acetyl-D-mannosamine, amygdalin, D-arabitol, arbutin,
D-fructose, L-fucose, D-gluconic acid, myo-inositol, $\alpha$-Dlactose, D-melezitose, D-melibiose, methyl $\alpha$-D-galactoside, methyl $\beta$-D-galactoside, methyl $\beta$-D-glucoside, methyl $\alpha$-Dmannoside, palatinose, D-psicose, D-raffinose, salicin, Dsorbitol, stachyose, sucrose, turanose, D-xylose, acetic acid, $\alpha$-hydroxybutyric acid, $\beta$-hydroxybutyric acid, $\gamma$-hydroxybutyric acid, $p$-hydroxyphenyl acetic acid, $\alpha$-ketovaleric acid, L-lactic acid, D-malic acid, methyl pyruvate, propionic acid, pyruvic acid, succinamic acid, succinic acid, $\mathrm{N}$-acetylL-glutamic acid, D-alanine, L-alanine, L-alanyl-glycine, Lasparagine, L-serine, putrescine, 2,3-butanediol, glycerol, inosine, thymidine, adenosine $5^{\prime}$-monophosphate, thymidine $5^{\prime}$-monophosphate, fructose 6-phosphate, glucose 6-phosphate and $\alpha$-DL-glycerol phosphate. The remaining 18 carbon sources tested could not be oxidized by the isolate.

DNA was extracted and purified as described previously (Kamagata \& Mikami, 1991). The DNA G +C content of ZFHKF- ${ }^{\mathrm{T}}$ was $40 \cdot 8 \mathrm{~mol} \%$, as determined by HPLC using LC-6A apparatus (Shimadzu) equipped with a UV detector (Shintani et al., 2000). For analysis of quinones, fatty acids and cell walls, cells of ZFHKF-1 ${ }^{\mathrm{T}}$ were harvested from cultures grown in Luria-Bertani medium. Quinones were extracted from freeze-dried cells by using chloroform/ methanol $(2: 1, \mathrm{v} / \mathrm{v})$ and $\mathrm{n}$-hexane. Extracts were purified using Sep-Pak Plus (Waters) (a cartridge type of silica gel containing spin purification column) and analysed by reverse-phase HPLC for identification (Tamaoka et al., 
1983). Whole-cell fatty acids were first converted, using anhydrous methanolic $\mathrm{HCl}$ (Komagata \& Suzuki, 1987), to methyl esters, which were then extracted by n-hexane for analysis by GC/MS (M7200A GC/3DQMS equipment; Hitachi). The capillary used was DB-5ms coated with $5 \%$ phenylmethylpolysiloxane at a thickness of $250 \mathrm{~nm}$ (Hanada et al., 2002). The presence of diaminopimelic acid isomers in the cell-wall peptidoglycan was determined by TLC (no. 5716; Merck) after hydrolysis with $6 \mathrm{M} \mathrm{HCl}$ at $100^{\circ} \mathrm{C}$ for 18 h (Komagata \& Suzuki, 1987). Fatty acid methyl ester analysis showed that ZFHKF- $^{\mathrm{T}}$ contained anteiso- $\mathrm{C}_{15: 0}$ $(67 \cdot 2 \%)$, iso- $\mathrm{C}_{15: 0}(21 \cdot 7 \%)$, with small quantities of iso$\mathrm{C}_{14: 0}(4 \cdot 7 \%)$, iso- $\mathrm{C}_{17: 0}(2 \cdot 7 \%), \mathrm{C}_{14: 0}(2 \cdot 2 \%)$ and iso$\mathrm{C}_{16: 0}(1 \cdot 6 \%)$. No unsaturated fatty acids were detected. MK-7 was the major quinone. The cell-wall peptidoglycan contained meso-diaminopimelic acid.

The 16S rRNA gene fragment was amplified from the suspended cells of ZFHKF- $1^{\mathrm{T}}$ by means of a whole-cell PCR using the Eubacteria-specific primer set of $8 \mathrm{~F}$ ( $5^{\prime}$-AGAGTTTGATCCTGGCTCAG-3'; positions 8-27, Escherichia coli numbering) and the prokaryote universal primer $1490 \mathrm{R}\left(5^{\prime}\right.$ GGTTACCTTGTTACGACTT-3'; positions 1491-1509, E. coli numbering) (Weisburg et al., 1991) in an automated thermal cycler (GeneAmp PCR 9700; Perkin-Elmer) (Zhang \& Fang, 2001). After purification using the Wizard PCR Preps DNA purification kit (Promega), the 16S rRNA gene fragment was sequenced using an autosequencer (ABI model 377A; Perkin-Elmer) and the dRhodamine Terminator Cycle Sequencing FS Ready Reaction kit (Perkin-Elmer) with the primer set of EUB8F, 1490R and 1055R (5'-CACGAGCTGACGACAGCCAT-3'). The 16S rRNA gene sequence was then manually edited using BioEdit (Hall, 1999) and compared, using a BLAST search, with the sequences of reference micro-organisms available in GenBank. The $16 \mathrm{~S}$ rRNA gene sequence was then aligned with the most similar 16S rRNA gene sequences of reference micro-organisms retrieved from GenBank, and checked manually using BioEdit. A phylogenetic tree was subsequently constructed using MEGA 2.1 software (Kumar et al., 1993).
On the basis of analysis of $1355 \mathrm{bp}$ of the 16S rRNA gene sequence, strain ZFHKF- ${ }^{\mathrm{T}}$ was found to be most closely related to three unidentified Bacillus species, including two deep-sea isolates, i.e. strain HTA437 (97\% similarity) and strain HTA506 (97\% similarity) (Takami et al., 1997), and the isolated bacterium strain 47083 (96\%) (Drancourt et al., 2000), as well as to two known species, i.e. Bacillus barbaricus (96\% similarity) (Täubel et al., 2003) and Bacillus megaterium (95\% similarity) (Suzuki \& Yamasato, 1994). The phylogenetic tree shown in Fig. 2 demonstrates that strain ZFHKF- $1^{\mathrm{T}}$ is a member of the genus Bacillus. On the basis of the widely recognized criterion in current bacteriology that bacteria with more than a $3 \%$ difference in $16 \mathrm{~S}$ rRNA gene sequences are of different species (Stackebrandt \& Goebel, 1994; Rossello-Mora \& Amann, 2001), ZFHKF- ${ }^{\mathrm{T}}$ is therefore a novel species of the genus Bacillus.

The phenotypic properties and fatty acid profiles of strain ZFHKF- $1^{\mathrm{T}}$ and its closest known species, B. barbaricus V2-BIII-A2 and B. megaterium DSM 32 , as well as $B$. funiculus NAF001, which has a similar long-chain morphology, are summarized in Tables 1 and 2. Although all of the closest relatives of Bacillus species together with strain ZFHKF- $1^{\mathrm{T}}$ share common fatty acid components, having anteiso- $\mathrm{C}_{15: 0}$ and iso- $\mathrm{C}_{15: 0}$ as the main constituents, there were clear differences among them in terms of physiological and biochemical traits. In particular, the isolate could be differentiated from the others in utilizing salicin and not utilizing D-trehalose. On the basis of these data, strain ZFHKF- $1^{\mathrm{T}}$ should be placed in the genus Bacillus as a novel species, for which the name Bacillus macauensis sp. nov. is proposed (in acknowledgement of the city in which it was first found).

\section{Description of Bacillus macauensis sp. nov.}

Bacillus macauensis (ma.cau.en'sis. N.L. masc. adj. macauensis pertaining to Macau, the city where the type strain was isolated).

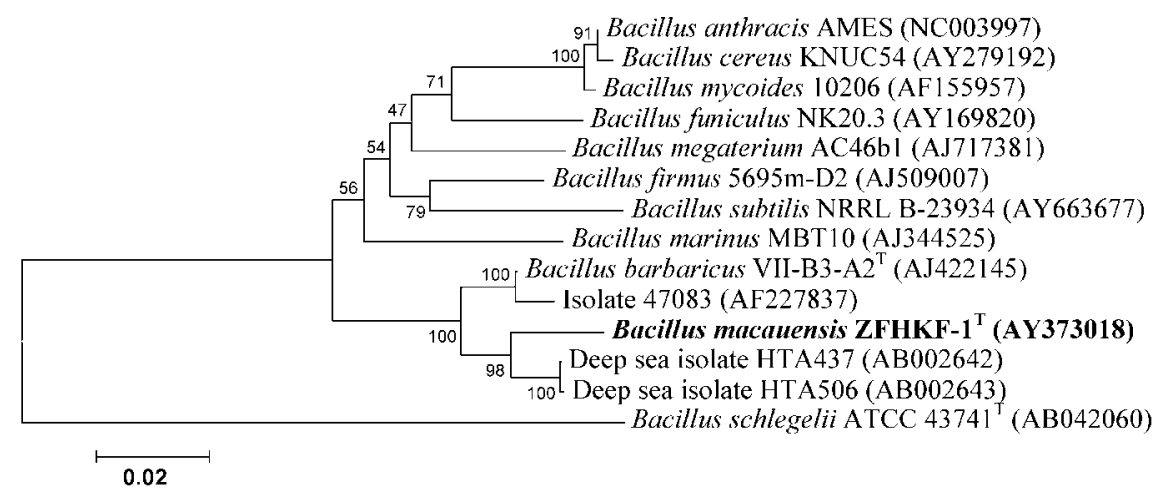

Fig. 2. Neighbour-joining tree based on $16 \mathrm{~S}$ rRNA gene sequences, using Jukes-Cantor distance, showing the phylogenetic relationships of ZFHKF-1 ${ }^{\top}$. Bootstrap values (expressed as percentages of 1000 replications) are shown at the branch points. Bacillus schlegelii ATCC $43741^{\top}$ was used as the outgroup species. Bar, 0.02 substitution per nucleotide position. 
Table 1. Differential morphological, physiological and biochemical properties of ZFHKF-1 ${ }^{\top}$ and related species

Strains: 1, ZFHKF-1 ${ }^{\mathrm{T}}$; 2, B. barbaricus V2-BIII-A2, data from Täubel et al. (2003); 3, B. megaterium DSM 32, data from Täubel et al. (2003); 4, B. funiculus NAF001, data from Ajithkumar et al. (2002). +, Positive; -, negative; ND, not determined.

\begin{tabular}{|lcccc|}
\hline Characteristic & $\mathbf{1}$ & $\mathbf{2}$ & $\mathbf{3}$ & $\mathbf{4}$ \\
\hline Long-chain morphology & + & - & - & + \\
Budding cells & - & - & - & + \\
Growth at pH 9.5 & + & + & - & - \\
Growth with 2\% NaCl & + & + & $\mathrm{ND}$ & - \\
Hydrolysis of: & & & & \\
Gelatin & + & $\mathrm{ND}$ & + & - \\
Tween 80 & - & - & + & - \\
Utilization of: & & & & \\
p-Arbutin & + & - & - & $\mathrm{ND}$ \\
D-Cellobiose & + & - & - & $\mathrm{ND}$ \\
D-Galactose & + & - & - & + \\
D-Mannose & + & + & - & $\mathrm{ND}$ \\
L-Rhamnose & + & - & + & $\mathrm{ND}$ \\
D-Ribose & + & + & - & + \\
Salicin & + & - & - & - \\
Sucrose & + & - & - & + \\
D-Trehalose & - & + & + & + \\
i-Inositol & + & - & + & - \\
D-Mannitol & + & - & + & $\mathrm{ND}$ \\
DL-Lactate & + & - & + & $\mathrm{ND}$ \\
L-Malate & + & + & - & - \\
Pyruvate & + & + & - & $\mathrm{ND}$ \\
DNA G+C content $(\mathrm{mol} \%)$ & $40 \cdot 8$ & $\mathrm{ND}$ & $37 \cdot 5$ & $37 \cdot 2$ \\
& & & & \\
\hline
\end{tabular}

ZFHKF- $1^{\mathrm{T}}$ cells (rod-shaped, $2 \cdot 0-5 \cdot 0 \mu \mathrm{m} \times 0 \cdot 8-1 \cdot 2 \mu \mathrm{m}$ ) form long unbranched chains over $100 \mu \mathrm{m}$ in length on agar as well as in broth. Gram-positive, catalase-positive, gelatinhydrolysing and endospore-forming. Grows at $20-40{ }^{\circ} \mathrm{C}$ (optimum $30^{\circ} \mathrm{C}$ ) and $\mathrm{pH} 6 \cdot 0-10 \cdot 0$ (optimum $\mathrm{pH} 8 \cdot 5$ ).

Table 2. Fatty acid content (\%) of $\mathrm{ZFHKF-1}{ }^{\top}$ and related species

Strains: 1, ZFHKF-1 ${ }^{\mathrm{T}} ; 2$, B. barbaricus V2-BIII-A2, data from Täubel et al. (2003); 3, B. megaterium DSM 32, data from Täubel et al. (2003); 4, B. funiculus NAF001, data from Ajithkumar et al. (2002).

\begin{tabular}{|lrrrc|}
\hline Fatty acid & $\mathbf{1}$ & $\mathbf{2}$ & $\mathbf{3}$ & $\mathbf{4}$ \\
\hline iso- $\mathrm{C}_{14: 0}$ & $4 \cdot 6$ & $9 \cdot 4$ & $6 \cdot 7$ & $0 \cdot 0$ \\
$\mathrm{C}_{14: 0}$ & $2 \cdot 2$ & $0 \cdot 9$ & $0 \cdot 0$ & $0 \cdot 0$ \\
iso- $_{15: 0}$ & $21 \cdot 7$ & $19 \cdot 0$ & $13 \cdot 9$ & $18 \cdot 0$ \\
anteiso-C $_{15: 0}$ & $67 \cdot 2$ & $42 \cdot 8$ & $70 \cdot 3$ & $44 \cdot 3$ \\
iso- $\mathrm{C}_{16: 0}$ & $1 \cdot 6$ & $6 \cdot 0$ & $0 \cdot 0$ & $3 \cdot 84$ \\
iso- $\mathrm{C}_{17: 0}$ & $2 \cdot 7$ & $0 \cdot 0$ & $0 \cdot 0$ & $1 \cdot 24$ \\
\hline
\end{tabular}

$\mathrm{NaCl}$ at $5-10 \%$ concentration inhibits its growth. Cellular fatty acids mainly comprise anteiso- $\mathrm{C}_{15: 0}(67 \cdot 2 \%)$ and iso- $\mathrm{C}_{15: 0}(21 \cdot 7 \%)$, with a little iso- $\mathrm{C}_{14: 0}, \mathrm{C}_{14: 0}$, iso- $\mathrm{C}_{16: 0}$ and iso- $\mathrm{C}_{17: 0}$. MK-7 is the major quinone. The cell-wall peptidoglycan contains meso-diaminopimelic acid. May oxidize $\beta$-cyclodextrin, cellobiose, D-galactose, gentiobiose, $\alpha$-D-glucose, lactulose, maltose, maltotriose, D-mannitol, D-mannose, 3-methyl glucose, L-rhamnose, D-ribose, sedoheptulosan, $\alpha$-ketoglutaric acid, L-malic acid, monomethyl succinate, L-glutamic acid, glycyl L-glutamic acid, uridine, uridine $5^{\prime}$-monophosphate and glucose 1-phosphate. The DNA G + C content of the type strain is $40 \cdot 8 \mathrm{~mol} \%$.

The type strain, ZFHKF-1 ${ }^{\mathrm{T}}\left(=\mathrm{JCM} 13285^{\mathrm{T}}=\mathrm{DSM} 17262^{\mathrm{T}}\right.$ ) was isolated from the drinking water supply of Macau, a city of subtropical climate in China.

\section{Acknowledgements}

The authors wish to thank the Seed Fund for Basic Research (grant no. 10205753) from the University of Hong Kong for the financial support of this study, and Akiko Ohashi for technical assistance.

\section{References}

Ajithkumar, V. P., Ajithkumar, B., Iriye, R. \& Sakai, T. (2002). Bacillus funiculus sp. nov., novel filamentous isolates from activated sludge. Int J Syst Evol Microbiol 52, 1141-1144.

Berkeley, R. C. W., Berkeley, R., Vos, P. D., Heyndrickx, M. \& Logan, N. (2002). Applications and Systematics of Bacillus and Relatives. Oxford: Blackwell Science.

Drancourt, M., Bollet, C., Carlioz, A., Martelin, R., Gayral, J. P. \& Raoult, D. (2000). 16S ribosomal DNA sequence analysis of a large collection of environmental and clinical unidentifiable bacterial isolates. J Clin Microbiol 38, 3623-3630.

Hall, T. A. (1999). BIOEDIT: a user-friendly biological sequence alignment editor and analysis program for Windows 95/98/NT. Nucleic Acids Symp Ser 41, 95-98.

Hanada, S., Takaichi, S., Matsuura, K. \& Nakamura, K. (2002). Roseiflexus castenholzii gen. nov., sp. nov., a thermophilic, filamentous, photosynthetic bacterium that lacks chlorosomes. Int J Syst Evol Microbiol 52, 187-193.

Kamagata, Y. \& Mikami, E. (1991). Isolation and characterization of a novel thermophilic Methanosaeta strain. Int J Syst Bacteriol 41, 191-196.

Komagata, K. \& Suzuki, K. (1987). Lipids and cell-wall analysis in bacterial systematics. Methods Microbiol 19, 161-203.

Kumar, S., Tomura, K. \& Nei, M. (1993). MEGA: Molecular Evolution Genetics Analysis software, version 1.0. University Park: Pennsylvania State University.

Rossello-Mora, R. \& Amann, R. (2001). The species concept for prokaryotes. FEMS Microbiol Rev 25, 39-67.

Shintani, T., Liu, W. T., Hanada, S., Kamagata, Y., Miyaoka, S., Suzuki, T. \& Nakamura, K. (2000). Micropruina glycogenica gen. nov., sp. nov., a new Gram-positive glycogen-accumulating bacterium isolated from activated sludge. Int J Syst Evol Microbiol 50, 201-207.

Stackebrandt, E. \& Goebel, B. M. (1994). Taxonomic note: a place for DNA-DNA reassociation and 16S rRNA sequence analysis in the 
present species definition in bacteriology. Int J Syst Bacteriol 44, 846-849.

Suzuki, T. \& Yamasato, K. (1994). Phylogeny of spore-forming LAB based on $16 \mathrm{~S}$ rRNA gene sequences. FEMS Microbiol Lett 115, 13-17.

Takami, H., Inoue, A., Fuji, F. \& Horikoshi, K. (1997). Microbial flora in the deepest sea mud of the Mariana Trench. FEMS Microbiol Lett 152, 279-285.

Tamaoka, J., Katayara-Fujimura, Y. \& Kuraishi, H. (1983). Analysis of bacterial menaquinone mixtures by high performance liquid chromatography. J Appl Bacteriol 54, 31-36.
Täubel, M., Kämpfer, P., Buczolits, S., Lubitz, W. \& Busse, H. J. (2003). Bacillus barbaricus sp. nov., isolated from an experimental wall painting. Int J Syst Evol Microbiol 53, 725-730.

von Klopotek, A. (1969). The turn direction of various strains of Bacillus cereus var. mycoides. J Zentralbl Bakteriol Parasitenkd Infektionskr Hyg 123, 683-684 (in German).

Weisburg, W. G., Barns, S. M., Pelletier, D. A. \& Lane, D. J. (1991).

$16 S$ ribosomal DNA amplification for phylogenetic study. J Bacteriol 173, 697-703.

Zhang, T. \& Fang, H. H. P. (2001). Phylogenetic diversity of a SRBrich marine biofilm. Appl Microbiol Biotechnol 57, 437-440. 